\title{
TENZIDEK VIZES OLDATÁBAN KÉPZŐDŐ MICELLÁK ALAKJÁNAK ÉS RÉSZECSKEMÉRETÉNEK MEGHATÁROZÁSA
}

\section{DETERMINATION OF PARTICLE SHAPE AND SIZE OF MICELLES FORMED IN AQUEOUS SOLUTION OF SURFACTANTS}

\author{
Nagy Roland ${ }^{1}$, Kothencz Réka ${ }^{2}$, Bartha László $^{3}$, Vágó Árpád ${ }^{4}$ \\ ${ }^{I}$ Pannon Egyetem, Mérnöki Kar, MOL Ásványolaj- és Széntechnológiai Intézeti Tan- \\ szék, Magyarország, Veszprém, Egyetem u. 10, Telefon: +3688/624-000/6175, \\ nroland@almos.uni-pannon.hu \\ ${ }^{2}$ Pannon Egyetem, Mérnöki Kar, MOL Ásványolaj- és Széntechnológiai Intézeti Tan- \\ szék, Magyarország, Veszprém, Egyetem u. 10, Telefon: +3688/624-000/6168, \\ kothenczr@almos.uni-pannon.hu \\ ${ }^{3}$ Pannon Egyetem, Mérnöki Kar, MOL Ásványolaj- és Széntechnológiai Intézeti Tan- \\ szék, Magyarország, Veszprém, Egyetem u. 10, Telefon: +3688/624-305, \\ bartha@almos.uni-pannon.hu \\ ${ }^{4}$ MOL Nyrt, KT Kutatás és Fejlesztés, Magyarország, Budapest, \\ Októberhuszonharmadikau.18, avago@mol.hu
}

\begin{abstract}
The association colloids are a special class of materials within the colloid chemistry since micelles are formed in appropriate circumstances. The particle size, the shape of micelles and two other surfactant characteristics of the mixture of various commercial, environmentally friendly non-ionic and anionic surfactants were investigated. Our goal was to prove the synergistic effect and interaction between the non-ionic and anionic surfactants.
\end{abstract}

Keywords: surfactant mixture, micelle, particle size, shape of micelles

\section{Összefoglalás}

Az asszociációs kolloidok egy külön anyagcsoportot alkotnak a kolloidkémián belül, mivel ezekből az anyagokból a megfelelő körülmények között kolloid méretü asszociátumok, micellák keletkeznek. Méréseink során különböző kereskedelmi forgalomban kapható, környezetbarát nemionos és anionos tenzidekből előállított tenzidkompozíciók részecskeméretét, a keletkezett micellák alakját és két hatásvizsgálati jellemzőjét vizsgáltuk. Célunk volt a közöttük feltételezett kölcsönhatás, szinergikus hatás kimutatása.

Kulcsszavak: tenzidkompozíció, micella, részecskeméret, micella alak 


\section{Bevezetés}

A tenzidek oldataiban megfelelő körülmények között micellák képződnek. A kialakult micellák szerkezete, alakja, mérete nagymértékben függ a körülményektől: a tenzid molekulaszerkezetétől, az oldószertől, a koncentrációtól, a hőmérséklettől, az oldott anyagok minőségétől és mennyiségétől, tehát mindazon tényezőktől, amelyek a kritikus micellaképződési koncentrációt (cmc) is meghatározzák $[1,2]$.

Ionos tenzidek elektrolitmentes vizes oldataiban a cmc-nél nagyobb, de nem túl nagy töménységnél képződő aggregátumok gömb alakúak. A micellák mérete az őket felépítő molekulák méretétől függ. Az alkillánc hosszának növekedésével növekszik a micella mérete is, az etilén-oxid-lánc méretének növekedésével viszont csökken.

A micellák mérete néhány esetben egyértelmüen növekszik a tenzid-koncentrációval, de általában kicsi a változás. Gyakran már kis koncentráció-növekedés hatására is henger alakúvá válnak a gömbmicellák [1].

Az alkalmazott tenzidek és kompozícióik vizes oldatát vizsgáltuk korábban kidolgozott és bemutatott módszerrel. Célunk volt molekulaalakjuk, részecskeméretük meghatározása és a közöttük feltételezett kölcsönhatás kimutatása.

\section{Felhasznált anyagok}

A vizsgálat során felhasznált egyedi, kereskedelmi forgalomban kapható nemionos és anionos tenzidek szerkezetét az 1. táblázat tartalmazza.

$\mathrm{Az}$ egyedi tenzidekből előállított tenzidkompozíciók összetételét a 2. Táblázatban láthatjuk.

A tenzidkompozíciók 50-50 tömeg\%ban tartalmazták a nemionos és anionos tenzideket. A vizsgálatok elvégzéséhez 1 tömeg\%-os tenzidoldatokat készítettünk.
1. táblázat. Egyedi tenzidek szerkezete

\begin{tabular}{|c|c|}
\hline Tenzid neve & Tenzid szerkezete \\
\hline SPAN 20 & szorbit-monolaurát \\
\hline SPAN 40 & szorbit-monopalmitát \\
\hline SPAN 60 & szorbit-monosztearát \\
\hline SPAN 80 & szorbit-monooleát \\
\hline NLES & nátrium-lauriléter-szulfát \\
\hline
\end{tabular}

2. táblázat. Tenzidkompozíciók összetétele

\begin{tabular}{|c|c|c|}
\hline $\begin{array}{c}\text { Tenzidkompozíció } \\
\text { jele }\end{array}$ & $\begin{array}{c}\text { Nemionos } \\
\text { tenzid }\end{array}$ & $\begin{array}{c}\text { Anionos } \\
\text { tenzid }\end{array}$ \\
\hline $\mathrm{T}-1$ & SPAN 20 & NLES \\
\hline $\mathrm{T}-2$ & SPAN 40 & NLES \\
\hline $\mathrm{T}-3$ & SPAN 60 & NLES \\
\hline $\mathrm{T}-4$ & SPAN 80 & NLES \\
\hline
\end{tabular}

\section{Alkalmazott módszerek}

\subsection{Részecskeméret analízis}

A kolloid oldatokban mérhető átlagos részecskeméretet és eloszlását Malvern Zetasizer Nano ZS típusú készülékkel határoztuk meg, amely a dinamikus fényszórás elvén alapul. A hidrodinamikai átmérő meghatározása a részecskék diffúziójából becsülhető a Stokes-Einstein összefüggés alapján történik. A készülék 633 nm hullámhosszú HeNe lézer alkalmazásával müködik. A különböző minták esetében a részecskeátmérőt (nm) az átlagos csúcsértékek alapján határoztuk meg. A mérési módszer körülményeit a Tanszéken korábban dolgoztuk ki [3].

\subsection{Vízben való oldhatóság}

A tenzidekből 1 tömeg\%-os oldatokat készítettünk és a vizes oldat zavarosságát száloptikás spektrofotométerrel határoztuk meg. A vízben való oldhatóságot a transzmittanciával jellemeztük $(0 \%$ teljesen zavaros, 100\% transzparens) [4].

\subsection{Emulgeáló hatás}

A minta emulgeáló hatásának megállapítása során $10 \mathrm{~cm}^{3}$ modell kőolajat és 10 $\mathrm{cm}^{3}$ térfogatú a tenzidkompozíciót 1 tömeg\%-ban tartalmazó desztillált vizes olda- 
tot mértünk méröhengerbe. Összeráztuk, majd 1 óra elteltével az emulziós fázis mennyiségét leolvastuk és térfogat\%-ban megadtuk [4].

\section{Mérési eredmények}

\subsection{Micella alak meghatározása}

A kialakult micellák alakjának meghatározásához olyan paramétereket használtunk fel, amelyek megadhatják a micellák legvalószínübb alakját.

A tenzid szénhidrogén farok részének hossza (1) és térfogata (2) empirikusan meghatározható Tanford és társai által alkalmazott módszer szerint [5].

$$
\begin{aligned}
& l=\left(0,154+0,1265 n_{c}\right) n m \\
& v=\left(27,4+26,9 n_{c}\right) \times 10^{-3}
\end{aligned}
$$

ahol

$\mathrm{n}_{\mathrm{c}}=$ szénatomszám a telített szénhidrogén láncban

$\mathrm{Az}$ átlagos móltört alapján a tenzid farok részének térfogata (v') és hossza (R) adható meg $(3,4)[6]$

$$
\begin{aligned}
& \mathrm{R}=\sum_{i=1}^{\mathrm{N}} \mathrm{x}_{\mathrm{i}} \mathrm{l}_{\mathrm{i}} \\
& \mathrm{v}^{\prime}=\sum_{i=1}^{\mathrm{N}} \mathrm{x}_{\mathrm{i}} \mathrm{v}_{\mathrm{i}}
\end{aligned}
$$

ahol

$\mathrm{x}_{\mathrm{i}}=\mathrm{az}$ i-edik komponens móltörtje a micellában

$\mathrm{l}_{\mathrm{i}}=\mathrm{a}$ szénhidrogén lánc hossza

$\mathrm{v}_{\mathrm{i}}=\mathrm{a}$ szénhidrogén lánc térfogata

$A z a_{0}$ paraméter bevezetésével figyelembe vesszük a tenzidek fej részének felületét és a közöttük kialakuló termodinamikai kölcsönhatást (5), így kiszámítható a packing paraméter $(\mathrm{P})$.

$$
\mathrm{P}=\frac{\mathrm{v}^{\prime}}{\mathrm{a}_{0} \mathrm{R}}
$$

Az egyenlet alapján számított packing paraméter a nemionos tenzidek esetén 0,142-0,179 és tenzidkompozícióik esetén 0,151-0,184 közötti tartományba esett, amely a szabad energia modell alapján egyensúlyi micella szerkezetet feltételez [7].

Tekintettel arra, hogy az egyedi tenzidek és tenzidkompozíciók esetén a $\mathrm{P}<1 / 3$, a lehetséges micella alak gömb, illetve ellipszoid, így azok mérete egymással összehasonlíthatónak tekintettük [7].

\subsection{Részecskeméret meghatározása}

Meghatároztuk a tenzidkompozíciók oldatának térfogat szerinti hidrodinamikai átmérőjét (3. táblázat és 1. ábra). A NLES részecskemérete $2,1 \mathrm{~nm}$ volt.

3. táblázat. Tenzidkompoziciók részecskemérete

\begin{tabular}{|c|c|}
\hline $\begin{array}{c}\text { Tenzidkompozíció } \\
\text { jele }\end{array}$ & $\begin{array}{c}\text { Hidrodinamikai } \\
\text { átmérö (nm) }\end{array}$ \\
\cline { 2 - 2 } & Térfogat szerint \\
\hline T-1 & 78,5 \\
\hline T-2 & 467,5 \\
\hline T-3 & 448,8 \\
\hline T-4 & 303,7 \\
\hline
\end{tabular}

1. ábra. Tenzidkompozíciók részecskemérete

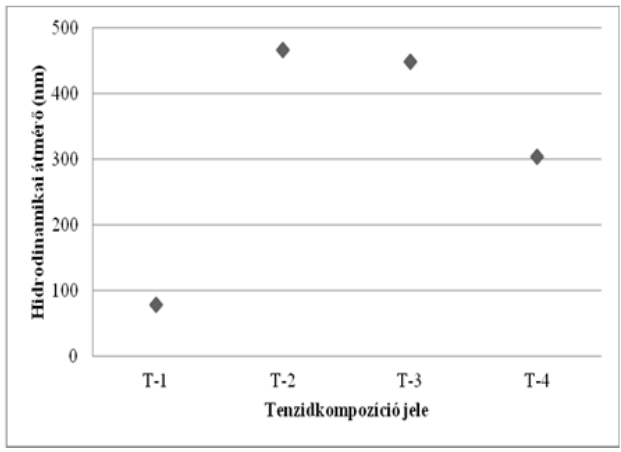

A vizsgált tenzidkompozíciók vizes oldatában kialakult micellák részecskemérete az anionos tenzid alkotta micellák részecskeméretéhez képest nagymértékü növekedést mutattak. A többszörösére növekedett részecskeméret alapján az anionos és nemionos tenzidek közötti pozitív kölcsönhatást valószínűsítettük.

Meghatároztuk a tenzidkompozíciók emulgeáló kapacitását és vízben való oldhatóságát (4. táblázat). 
4. táblázat. Tenzidkompozíciók emulgeáló hatása és vízben való oldhatósága

\begin{tabular}{|c|c|c|}
\hline $\begin{array}{c}\text { Tenzid- } \\
\text { kompozíció } \\
\text { jele }\end{array}$ & $\begin{array}{c}\text { Emulgeáló } \\
\text { hatás, V/V\% } \\
\left(1 \text { óra, } 25^{\circ} \mathrm{C}\right)\end{array}$ & $\begin{array}{c}\text { Vízben } \\
\text { való oldha- } \\
\text { tóság, } \%\end{array}$ \\
\hline $\mathrm{T}-1$ & 22,5 & 80 áttetszö \\
\hline $\mathrm{T}-2$ & 40,0 & 28 opálos \\
\hline $\mathrm{T}-3$ & 45,0 & 31 opálos \\
\hline $\mathrm{T}-4$ & 32,5 & 68 áttetszö \\
\hline
\end{tabular}

A NLES teljes mértékben (100\%) oldódik vízben és emulgeáló kapacitása 10 V/V\%. Megállapítottuk, tenzidkompozíciók esetén a növekvő vízben való oldhatóság csökkenti az emulgeáló képességet, amely a kompozíció HLB értékének a növekedésével magyarázható. A tenzidkompozíciók vizes oldatában kialakuló micellák részecskeméretének növekedése a vízben való oldhatóságának csökkenését eredményezte, melyet már a korábbi méréseinkkel igazoltunk [3]. Megállapítottuk, hogy a tenzidkompozíciók bemutatott tulajdonságai javultak az anionos tenzidhez képest, melyet a kialakult kölcsönhatás okozhat.

\section{Következtetések}

Kereskedelmi forgalomban kapható tenzidek és kompozícióik vizes oldatának molekulaalakját, részecskeméretét és a tenzidkompozíciók két hatásvizsgálati jellemzőjét vizsgáltuk.

Az eredmények alapján a következő megállapításokat tettük:
- az egyedi tenzidek és tenzidkompozíciók esetén a lehetséges micella alak gömb, illetve ellipszoid;

- az anionos tenzidhez képest többszörösére növekedett részecskeméret alapján az anionos és nemionos tenzidek közötti pozitív kölcsönhatást valószínüsítettük;

- a növekvő vízben való oldhatóság csökkentette a tenzidkompozíciók emulgeáló képességét.

$\mathrm{Az}$ eredmények alapján a nemionos és anionos tenzid között kölcsönhatást feltételeztünk.

\section{Szakirodalmi hivatkozások}

[1] Shaw, D.J.: Bevezetés a kolloid-és felületi kémiába, Müszaki Könyvkiadó, Budapest 1986

[2] Szántó F.: A kolloidkémia alapjai, Budapest, 1987

[3] Nagy R. et al.: Study on characteristics of micelles formed by surfactants and polymer mixtures for EOR, 6th International Conference on Safety \& Environment in Process \& Power Industry -13-16. April, 2014, Bologna, Italy

[4] Becher P.: Emulziók, Müszaki könyvkiadó, Budapest, 1965

[5] Tanford C., J. Polym. Sci. Pol. Lett. 18, 1980, 687

[6] Anachov S.E. et al: Disclike vs. cylindrical micelles: generalized model of micelle growth and data interpretation, J. Colloid Interf. Sci, 416, 2014, 258-273

[7] Mandal A. et al: A thermodynamic assessment of micellization for a mixture of sodium dodecyl benzene sulfonate and Tween 80 surfactants for ultralow interfacial tension, F. Phase Equi., 408, 2016, 212-222 